\title{
O sonho diurno e a metáfora noturna
}

\section{Aguinaldo J. Gonçalves}

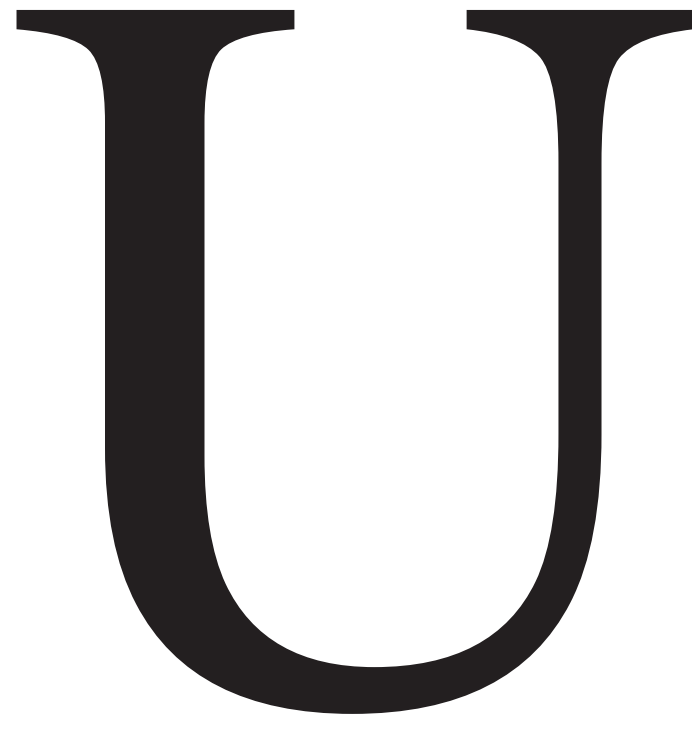

ma face e outra face do mesmo recorte implicam o procedimento lunar da busca da essência das coisas. As formas inaudíveis ressoam das vozes ecoadas cuja origem não se define nem se aponta o ponto de onde ela parte para eclodir no vasto fio da infindável noite. Ela, a noite, é incomensurável para que se possa determinar algum elemento definitivo no contorno do espaço sideral e metafórico. A metáfora encontra na noite o que não possui em si mesma: moldura do que não é salientável 
dentro do equilíbrio que se vasculha nesta vida de rascunhos e mais rascunhos na tentativa de arranhar os contornos ásperos do silêncio. Se a noite não fosse a noite, poder-se-ia ter nela um apoio ou um suporte na esfera cognoscível dos volumes violáveis. Mas a noite não é determinada pelo controle vivencial dos referentes e das vontades materializadas dentro das camadas reconhecíveis do imediatamente captável pela carne, nem pelo que os órgãos do sentido tangenciam, como a esfera do conforto que tocamos, colocamos nossas mãos e nossos pés, cheiramos, buscamos pela boca o sabor na língua; enfim, envolvemos o máximo possível nossos órgãos na tentativa de conhecer ou reconhecer o que nos acostumamos denominar de vida. Isso tudo ocorre dentro da perscrutação diurna que acreditamos vivenciar, mas que na verdade são sonhos peregrinadores que vivenciamos desde o momento em que nascemos e, por analogia, ficamos sempre estupefatos diante de cada gesto, à luz do sol ou no delineio das sombras, naquela hora em que o verde dos renques de árvores se enfileira em matizes de verdes: verde-água, verdemusgo, "verde menos verde", verde verde.

\section{O TERRITÓRIO DA NOITE: UMA METÁFORA}

Tudo isso compõe o cair das sombras, ponto de partida para o nascimento da metáfora noturna. Todo sonho prismado com o contorno de realidade em que os sentidos lidam com cada referente do mundo, como se fosse realidade na ilusão de que se conhece o que se vê e o que se vive, mas não se vivencia, pois se assim fosse, mediante cada contorno de forma ou de cor, cada dispositivo formal dos elementos dispostos no mundo, entendidos como sonhos, nos conduziria ao entre-sonhos e nos aproximaria não da verdade, mas da validade que relativiza o universo visível das coisas e explicitaria a face invisível do mundo. É no dia que a subversão da percepção nos domina e é no dia que a falsa crença da existência das coisas mostra sua cara e faz com que o sonho tremeluza na oportunidade de reconhecer-se como metáfora, à luz do sol e ao cair das sombras. Falamos aqui da experiência sensível de relação entre nosso sentido diante das coisas e de nosso pensamento no sentido desta relação, pois é a partir desse ponto que tudo se inicia. A partir do momento em que o nosso tato toca e sente a superfície da matéria sem nos iludir pelo procedimento traiçoeiro da antimetáfora é que começamos a vislumbrar o início da vibração de nós mesmos, de nosso corpo, de nosso pensamento frente às coisas e da relativização do que acreditamos ser as coisas que se tornam móveis diante de nossos olhos ou de nosso pensamento para que possamos construir uma certeza sem certeza, uma espécie de plasmação do incerto, e dentro desse processo nos tornamos incertos para nós mesmos. Durante estas reflexões ou deste ziguezaguear deste pequeno ensaio, estaremos indo e vindo num movimento pendular entre o sonho diurno e a metáfora noturna, tendo sempre o universo de um invadindo o universo do outro sem que haja divisórias entre ambos. $\mathrm{Na}$ verdade, o propósito destas ideias sem fim nem princípio, mas com o ímpeto de uma determinação, surge das camadas que se sobrepõem nos ninhos ou dos nichos de significação que pesam na noção constru- 
tiva de vir a ser, do modo de viver, de se fazer entender, de acreditar que seja o olhar com certeza do homem prostrado às duas horas da tarde olhando para algum ponto com lentes escuras e tendo certeza para que lado se dirigirá em busca de algo que sabe que irá encontrar. Este homem não conhece a metáfora. A sua precisão solar revela a sua total incapacidade de ver; no sonho deste homem a luz do sol não existe, mas ele tem certeza. Seguindo um caminho sem aclive e sem declive dentro daquela reflexão sobre o sonho diurno, passamos ao referencial textual. Seja o texto verbal, seja o texto visual, para realizarmos um procedimento analógico entre a percepção situacional e a linguagem, damos aqui um passo mais expansivo. Refiro-me ao contexto artístico. O denominado discurso verbal literário consiste numa tentativa do homem de se valer de uma retórica que subverta as medidas da linguagem-padrão em busca de uma sensibilização dos recursos estilísticos para que se atinja a composição de uma esfera distinta da linguagem em busca de uma expressão no mundo e em busca da transmissão dessa expressão ao outro, de modo a mobilizar seus estigmas e seus valores para conduzi-los a alguma forma de crescimento. Este sonho diurno das palavras ou das imagens acredita estar recriando o mundo por um esfacelamento das camadas referenciais deste mundo. Trata-se de um uso retórico da linguagem que, na maioria das vezes, consiste num enorme valer-se de um modo ingênuo e sofisticado de um sonho diurno; "desculpo-me da intensidade hiperbólica da expressão": isso atinge a grande maioria das manifestações retóricas e tudo é chamado de literatura quando quase sempre corresponde ao tênue estilo de maquiar as palavras, esperando transmitir um sentimento ou uma ideia dentro de um tom com ares de verdade ou com noções subjetivas e ornamentadas por aparatos verbais que trazem em si ressonâncias de uma tradição de um legado, de outras vozes que também realizaram o mesmo procedimento, sendo que alguns se perderam na história das formas e outros se mantiveram persistentes na memória da tradição e foram transportados ou atualizados para este eterno presente de transfusão sanguínea, carregando o mesmo poder de persuasão retórica e se apresentando com uma máscara desfalecida e com ares de "sonho diurno". Tudo que foi até aqui considerado nesse procedimento entre os referenciais do mundo e procedimentos retóricos verbais literários vale para linguagens construídas com outros meios expressivos (pintura, escultura e outras formas de artes plásticas). Devemos assinalar, aqui, que as questões dos sonhos diurnos mais ainda se acentuam em se tratando pela criação artística das artes plásticas, uma vez que a transmutação dos signos depende da competência do olhar e do modo de construir no objeto que se fabrica um modo de "descascar" as esferas da referência para que se procure se aproximar do que seria a substância do mundo.

$\mathrm{Na}$ tradição retórica da metáfora desde os gregos até a modernidade, alguns equívocos têm ocorrido com insistência nas considerações teóricas, sejam acadêmicas, sejam didáticas, que mais e mais transmitem falsas consciências em relação à mais relevante figura do pensamento estilístico. Esses equívocos se dão no fundamento básico da metáfora e, se não fossem eles, seriam muito mais equilibradas e lógicas as possibilidades de construção da metá- 
fora, bem como de sua compreensão num contexto textual de qualquer natureza. O que denominamos de equívoco consiste em aproximar a figura da metáfora à figura da comparação ou símile, que representa o outro vértice equacional das relações semânticas. Na comparação temos explicitamente a ocorrência de uma relação entre termos determinantes que são: o elemento comparado e o termo comparativo, unidos pelo componente linguístico da relação. Esse termo linguístico vai determinar o tipo de relações comparativas tais como "mais que", "menos que", "tanto quanto", "como", "igual a" e assim outros. Nesse tipo de relação os elementos da comparação mantêm suas identidades e isso é fundamental para determinar o procedimento equacional dessa figura. A figura que tangencia de modo incômodo a figura da metáfora é a catacrese, que diríamos se tratar de uma figura que não é figura; é um incômodo da retórica, pois significa apenas o uso de um termo linguístico ou de um lexema ao invés de outro, por uma espécie de empréstimo semântico: boca do forno, barriga da perna e céu da boca são exemplos clássicos dessa forma de expressão muito distante do que poderíamos compreender como metáfora. Voltando ao equívoco anteriormente assinalado, quanto mais aproximada a figura da metáfora da comparação, mais destituída da metáfora está sua natureza essencial.

\section{UM CONCEITO: A METÁFORA}

A metáfora, no seu sentido primordial e essencial, consiste num processo de interação semântica entre universos distintos de sentido. A palavra "interação" traz em si todo o procedimento de anulação do equívoco a que acima nos referimos. Essa figura talvez seja a mais relevante da retórica. Ela atua com intensidade sobre a significação das palavras e das coisas. Por isso sua grandeza e por isso a necessidade de compreendermos com certa precisão o seu conceito. Mas também devemos assim assinalar os graus de sua complexidade. A metáfora existe por necessidade de nomearmos aquilo que não pode ser nomeado diretamente por uma palavra ou por um signo representativo; se isso fosse possível, não teríamos necessidade da metáfora. Por isso, na vaguidão semântica entre um signo ou uma expressão e um outro signo e outra expressão, na busca de uma nomeação do inominável, surge a profusão interativa dos traços semânticos e nasce assim a metáfora. Claro está que realizada qualquer tendência de interação semântica, já se considera uma metáfora, mas isso não significa que tenhamos efetivamente a metáfora no seu sentido mais decisivo e profícuo. Na maioria das vezes, quando o sentido de uma palavra resvala no sentido de outra, costuma-se já considerar a resultante como metáfora. Sendo assim, a metáfora perpassa vários graus de produção e de realização gerando efeitos de sentidos com menor ou maior intensidade semântica. Esse tipo de grau evolutivo da metáfora depende do grau de abertura da intersecção que ocorre entre o elemento metaforizante e o elemento metaforizado, onde bailam os semas que vão conviver e se inteirar no procedimento metafórico. Quanto maior o grau de interação sêmica, mais a metáfora se imporá como metáfora. Por isso consideramos frágeis as consideradas "metáforas de uso", constituídas da relação $x$ é $y$ em que os dois 
termos se manifestam. Nesse universo se encontram as metáforas de uso tais como "aquela mulher é uma onça", mas podendo ocorrer certa metáfora expressiva como na poesia de Fernando Pessoa "Meu coração é um rio subterrâneo": mais abstrata que a anterior, mas ainda marcada por termos concretos. Temos a metáfora em que os dois termos são separados por preposição: "lábios de mel" (romance Iracema, de José de Alencar) ou "olhos de ressaca" (romance Dom Casmurro, de Machado de Assis). Num terceiro grau de manifestação temos apenas a presença do elemento metaforizado, o que faz a metáfora atingir uma gama semântica mais elevada. Depois desse painel de graus metafóricos, temos uma elevada dimensão da metáfora que vem sendo refletida neste artigo. Para que se possa falar de uma metáfora de alto grau construtivo e relacional, temos de atingir dimensões semânticas bastante abstratas e a metáfora deve atingir as camadas do discurso, o que denominamos de metáfora discursiva. Nesse universo desaparecem os traços semânticos dos elementos metaforizadores, permanecendo os rastros das unidades sêmicas na construção daquilo que na esfera referencial não conseguimos nomear; daquilo que o filósofo da linguagem L. Wittgenstein denominaria de inefável.

A inefabilidade do discurso artístico (seja constituído pela semiótica verbal, seja constituído pela semiótica visual) vai-se conformar figurativamente na metáfora engendrada numa dimensão elevada de manifestação. As grandes obras se realizam por meio da competência do artista em romper com os limites da referencialidade e atingir planos de significação inusitados em que os signos e semissímbolos se amalgamam para a composição do tangível e atinjam o receptor nos seus pontos mais veneráveis, que jamais poderiam ser atingidos por meio de metáforas fáceis, flébeis, como assinalamos anteriormente. Neste ponto devemos assinalar alguns aspectos da criação artística que promovem esse processo de composição da metáfora. Referimo-nos ao conceito de "motivação do signo" já prenunciado pelos gregos, sobretudo por Platão, e confirmado por outros grandes pensadores da linguagem. Na modernidade, a motivação dos signos foi teorizada por Ferdinand de Saussure na linguística e assinalada como fundamento da relevância desse processo de motivação. Na criação artística o processo de motivação faz com que se acentuem as noções de semissímbolos, que são fundamentais para a construção do processo metafórico em nível mais elevado. Como já viemos teorizando em outros trabalhos, a obra de arte deve se realizar em três dimensões distintas: composição, realização e modulação. Esse último procedimento trabalha as gamas de motivação do signo e o modo como operar na formulação da metáfora discursiva.

Ao se relacionar com uma obra altamente modulada e consequentemente metaforizada, o receptor não pode esperar desse tipo de obra imagens alegóricas que driblam o teor metafórico propriamente dito para ilustrar a obra com figuras retóricas, diversificadas e sem verdadeira substância significativa. Na literatura esse processo se dá de maneira profusa, em que as imagens verbais acabam por delinear dimensões icônicas da linguagem.

A metáfora discursiva advinda do processo de modulação da linguagem é responsável pelos discursos promovedores de intertextos 
advindos dos movimentos semânticos que muitas vezes denominamos palimpsestos, que promovem isotopias inusitadas num entrecruzar do genotexto e do fenotexto dentro da concepção da semiótica de Julia Kristeva. Esse tipo de engendramento literário só é possível em autores produtores de obras de intensa complexidade. É incongruente imaginar um trabalho literário mediano gerador de uma metáfora discursiva dessa natureza; e isso engloba tanto as artes verbais, quanto as artes visuais. Mesmo que não comporte neste artigo a análise de obras, é mister que exemplifiquemos o que vem sendo discutido. Iniciemos com um poema de João Cabral de Melo Neto intitulado "Dentro da perda da memória", do livro A pedra do sono (1942):

\section{"Dentro da perda da memória uma mulher azul estava deitada que escondia entre os braços desses pássaros friíssimos que a lua sopra alta noite nos ombros nus do retrato.} E do retrato nasciam duas flores (dois olhos dois seios dois clarinetes) que em certas horas do dia cresciam prodigiosamente para que as bicicletas de meu desespero corressem sobre seus cabelos.

E nas bicicletas que eram poemas chegavam meus amigos alucinados. Sentados em desordem aparente, ei-los a engolir regularmente seus relógios enquanto o hierofante armado cavaleiro movia inutilmente seu único braço".

O próprio título do poema indicia a desconstrução da referencialidade para a construção do universo metafórico. "Per- da da memória" implica afastamento das relações de lembrança dos liames com as coisas mundanas para penetrar no universo das imagens, no fluxo das sensações em que uma verdadeira intersecção em nível profundo ocorra entre a tangibilidade das coisas e a esfera dos sentimentos profundos mantidos pela inter-relação e evocação das imagens que tocam várias camadas de nossa sensibilidade. Esse poema de João Cabral é "monitorado" pela imagem central da bicicleta, que nos dá a impressão de provocar o movimento nas imagens que por si sós vão criando novos tipos de intersecção e formando o labirinto lógico das ideias. Os elementos imagéticos se conectam de modo a apresentarem um movimento peculiar da metáfora. Devemos aqui lembrar, a propósito, uma riquíssima conceituação de metáfora realizada pelo poeta alemão Hölderlin nos idos de 1800. Para ele, o poema lírico consiste na metáfora contínua de um sentimento único. Como se nota, a conceituação de Hölderlin vai ao encontro, com exatidão, do poema de João Cabral. O movimento das imagens inscrito no poema é corroborado pela integração das imagens que o compõem. A própria noção de tempo é figurativizada pela imagem do hierofante que move "inutilmente seu único braço". Isso tudo é possível por se tratar de um poema que possui a competência de absorção do mito e da linguagem e em que a metáfora ocorre em seu esplendor sem trazer em si os ranços da ilustração ou dos "enfeites retóricos". Uma vez que o poema lírico é considerado um discurso circular, ele espelha o teor da metáfora que, por si, materializa na poesia a circularidade.

Passemos agora a um caso exemplar de metáfora "discursiva" nas artes plásticas: 


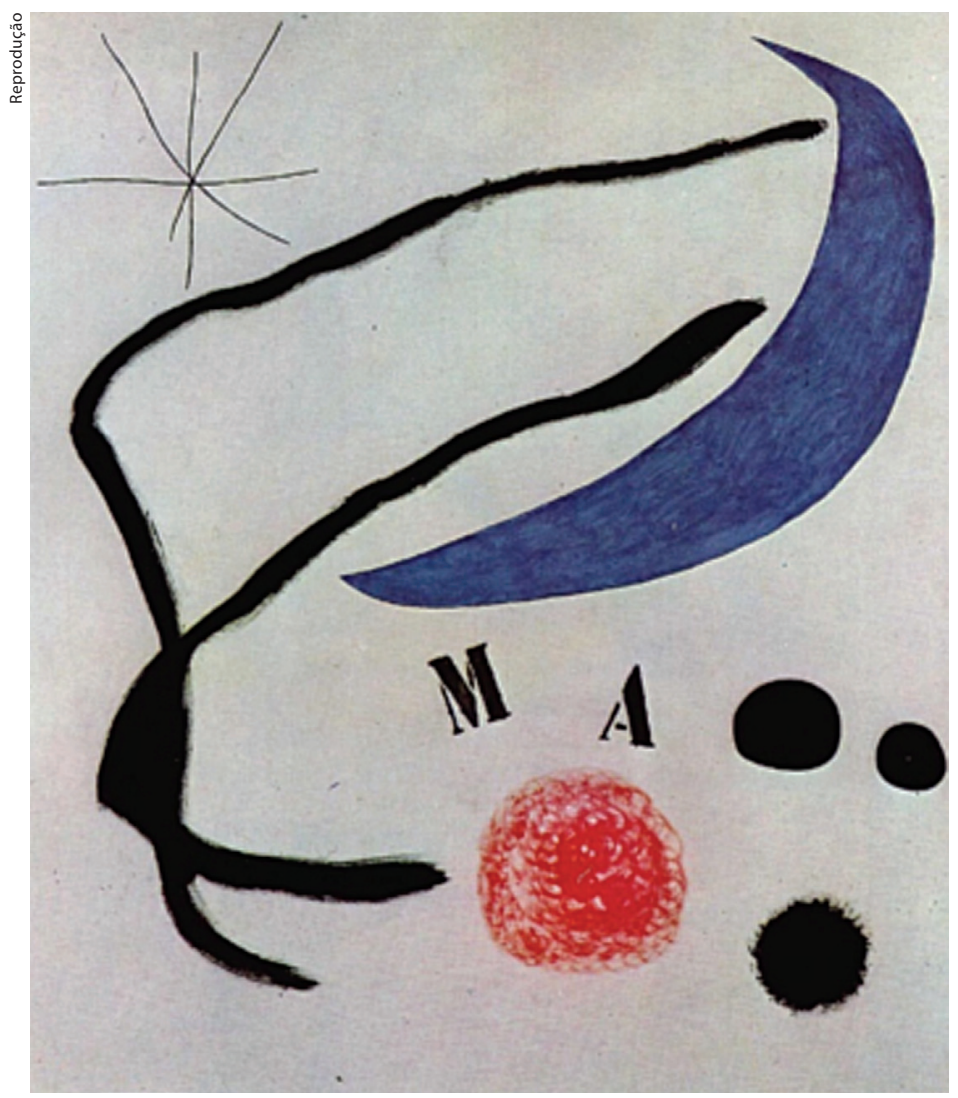

Joan Miró, Poema I, 1968

O pintor catalão Joan Miró, desde o início de sua produção plástica, no começo do século $\mathrm{XX}$, teve como exercício permanente um trabalho de desreferencialização. Em momento algum esse pintor se deixou conduzir pelas rédeas ou pelos caminhos que as escolas de seu tempo tentavam lhe impor. Mesmo a escola surrealista, com seus melhores representantes, tentou lhe impor a sua tendência ao figurativo e à dissoluta forma de representação plástica, mas Miró seguiu sempre seus próprios passos. Dentre os traços de estilo de sua pintura, a deslexicalização e a construção da alegoria foram seus pontos fortes, até, paulatinamente, atingir o âmago da construção metafórica, e nessa forma o que vimos discutindo destaca-se com intensidade exemplar: o nível eidético (camada formal) se alia às linhas e às cores num plano altamente modulado da metáfora.

Essa forma de pintura mobiliza todos os planos de articulação icônica e acaba por construir uma expressão que atinge o receptor de uma maneira aparentemente enigmática; queremos dizer, pois, que a profusão metafórica não consiste, como adiantamos, numa relação em que $x$ é $y$ ou, para melhor, $a$ que se intersecciona a $b$ conduzindo a $c$, como quer a retórica clássica. Na verdade, a intersecção entre $a$ e $b$ conduz a $n$ ou a um enigma. A metáfora em Miró envolve não apenas formas, linhas e cores, mas envolve sua concepção de moldura e a dinâmica que se instaura entre todos os elementos modulados no interior da tela. Tudo isso cria na pintura desse artista catalão uma ilusão do 
lúdico e da visão infantil de mundo levando muitos a assim compreendê-la. Nisso sua pintura engana, diferente do poema de João Cabral, em que as imagens se impunham pela sua complexidade e pela sua difícil compreensão; mas a metáfora discursiva de Joan Miró não é mais fácil que o intenso poema de João Cabral.

O terceiro passo da apresentação deste exemplário optou pela escolha de um texto considerado narrativo para que se possa compreender a metáfora discursiva em todos os seus ângulos. Se bem que a metáfora no sentido que vimos discutindo desde o princípio deste artigo possui aspectos peculiares que não se alteram independente do gênero em que se manifesta. Além disso, há de se notar que o gênero narrativo, em certos casos, possui um grau de poeticidade de singularidade difícil de encontrar nos textos literários em versos. Passemos a tratar, a propósito, de um caso singular: uma passagem do pequeno conto "Uns inhos engenheiros" de João Guimarães Rosa, contido na obra póstuma Ave, palavra (1970).

"Onde eu estava ali era um quieto. $\mathrm{O}$ ameno âmbito, lugar entre-as-guerras e invasto territorinho, fundo de chácara. Várias árvores. A manhã se-a-si bela: alvoradas aves. $\mathrm{O}$ ar andava, terso, fresco. O céu - uma blusa. Uma árvore disse quantas flores, outra respondeu dois pássaros. Esses, limpos. Tão lindos, meigos, quê? Sozinhos adeuses. E eram o amor em sua forma aérea. Juntos voaram, às alamedas frutíferas, voam com uniões e discrepâncias. Indo que mais iam, voltavam. O mundo é todo encantado. Instante estive lá, por um evo, atento apenas ao auspício.

$[\ldots]$
O ninho - que erguem - é néxil, pléxil, difícil. Já de segredo o começaram: com um bicadinho de barro, a lama mais doce, a mais terna. De barro, dos lados, à vária vez, ajuntam outros arrebiques. À muita fábrica, que se forma de ticos, estilhas, gravetos, em curtas proporções; e argueiros, crinas, cabelos, fibrilas de musgos, e hábeis ciscos, discernidas lãs, painas - por estofo. Com o travar, urdir, feltrar, enlaçar, entear, empastar, de sua simples saliva canora, e unir, com argúcia e gume, com - um atilho de amor, suas todas artes. Após, ao fim, na afofagem, forrá-lo com a própria única e algodoída penugem do peito, a que é mais quente do coração. $\mathrm{O}$ ninho - que querem - é entre asas e altura. Como o pássaro voa trans abismos. A mais, num esperanceio: o grácil, o sutil, o pênsil."

Devemos atentar para o desenho que cada um dos exemplos traz na metáfora discursiva e nas implicações sensitivas e significativas geradas pelo objeto apresentado. Sabe-se que abordar em linhas gerais um texto de Guimarães Rosa é praticamente impossível e pode trazer resultantes perigosas para a realidade do texto. Como a obra do autor mineiro é extensa e de excelência, decidimos optar por este fragmento no qual se pode deslumbrar elementos da metáfora discursiva por meio de procedimentos só encontrados em Guimarães Rosa. Lendo atentamente a passagem, notamos que os aspectos da linguagem saltam aos nossos olhos. Torna-se mais difícil argumentar a favor de uma narrativa do que a favor de uma poesia. O plano de expressão é eximiamente trabalhável e nele as figuras de som, as imagens sonoras farfalham entre tons e cores em que a linguagem fonologicamente reorganiza seus fonemas, gerando conjuntamente os desenhos que nos deixam 
atônitos sem muito entendermos o que está acontecendo. Num turbilhão de formas sonoras conjugam-se aliterações, coliterações, assonâncias, paronomásias, poliptoto, rimas internas, onomatopeias, figuras que com outras formas de expressão criam o arcabouço fonético/fonológico no processo de composição semissimbólica do discurso. Daí vem a dinâmica efervescente do discurso de Guimarães Rosa construindo a metáfora absoluta em que, por meio do ninho dos pássaros, nasce a imagem do poema lírico e isso consistindo no reino da bricolagem, numa permanente forma metalinguística do discurso. Apesar de pertencer ao gênero narrativo, "Uns inhos engenheiros" pode ser considerado o que denominamos "narrativa poética". Assim sendo, o próprio teor de prosa que determina a base do texto se torna de alta poeticidade e os elementos da linguagem interceptam o segmento natural da narrativa.

Um pouco distinto, mas igualmente intenso e metafórico, segue-se o ultimo exemplo. Trata-se do quadro Os amantes, de René Magritte.
O teor metafórico não só deste quadro, mas da obra de René Magritte, compõe-se de estruturas metonímicas. Sua obra sempre parte de figuras em relação de contiguidade e na sua forma de construção nasce a relação metafórica por similaridade. A pintura desse artista belga trabalha na maioria de seus casos com o eixo paradigmático na busca de semelhanças e dessemelhanças para a construção do resultado da imagem. Sua obra caracteriza-se pela capacidade de síntese nos levando sempre a analisar o título de cada um de seus quadros. São eles muitas vezes que nos levam à construção metafórica da imagem. No quadro em questão, no eixo paradigmático são duas cabeças (que se pode considerar sinédoques) de seres que inferimos tratar-se de gêneros diferentes (um homem e uma mulher), mas que não temos certeza uma vez que se trata de ícones, isto é, signos e não referentes. Ao buscar essa referência possível temos a impossibilidade, pois os ícones das cabeças são envolvidos por um tecido que tira qualquer possibili-

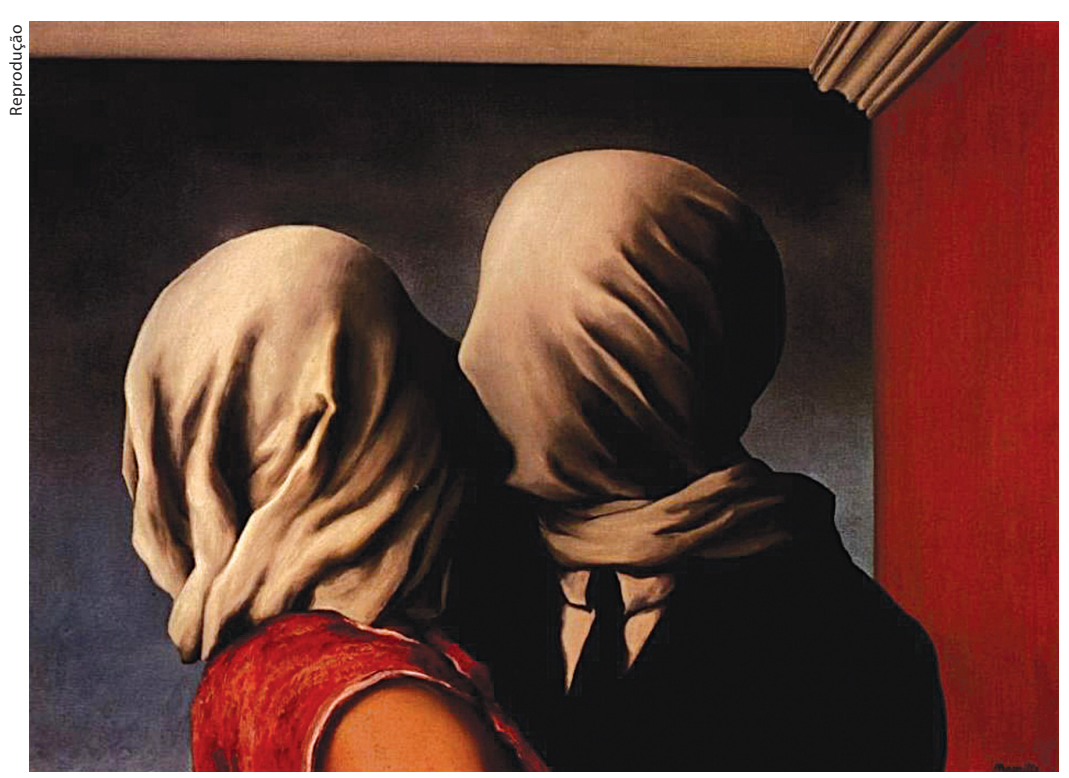

René Magritte, Os amantes, 1928 
dade de uma interação afetiva. Os ícones são metonímias de dimensão associativa e o que nos resta no conjunto são simulacros semióticos, como se dissesse a nós como nos dissera no quadro do cachimbo: "Isto não são amantes", e essa noção semiótica se repete em muitos outros quadros.

Mitigar as investigações sobre a metáfora e seus movimentos tensivos é obliterar as evidências do que se propõe a se esconder sob os escombros dos desmandos dos sentidos. Essa figura nuclear da retórica dribla e, ao mesmo tempo, argumenta em favor dos juízos semânticos desde que o homem vislumbrou manifestar-se ou expressar-se dubiamente em forma de expressão verbal ou extraverbal. Uma vez que o princípio da metáfora advém de processo de interação de sentidos para criar novos sentidos que nomeiem ou denominem algo que não seria possível ser nomeado com precisão, a metáfora não pode ser criada trazendo no seu corpo pedaços dos sentidos oriundos dos mundos das referências que não precisam ser renomeados. É trabalhoso repensarmos a metáfora ou pensarmos a metáfora como se fosse pela primeira vez. Os elementos linguísticos e retóricos que atuam na construção da metáfora prescindem de qualquer reflexão sobre a metáfora. Como pensar com acuidade sobre a conotação se não temos o mínimo de entendimento sobre a denotação? Para aquém de uma forma de vermos o mundo por meio da metáfora, temos de instigar os entremeios por meio de um conhecimento mínimo das ordens das coisas e dos sentidos das coisas do mundo. Isso é necessário para que possamos caminhar na direção do esgotamento de sentidos a ponto de nos valermos de uma metáfora ou reconhecermos num contexto verbal as marcas de uma metáfora para atingirmos a precisão que um signo ou que mais de um signo não consigam apreender.

A face da noite naquela instância em que não se ouve nada a não ser o silêncio da noite em que o cão já não late, o pipiar dos pássaros se cala e o uivar de vozes indefensáveis se mortifica - neste instante a noite apresenta o que ela possui de essencial para que seja oferecida ao artista como metáfora.

\section{REFERÊNCIAS}

HÖLDERLIN, F. Reflexões. Trad. Márcia de Sá Cavalcante e Antonio Abranches.

Rio de Janeiro, Relume-Dumará, 1994.

MELO NETO, J. C. de. Obras completas. $1^{\text {a }}$ ed. Rio de Janeiro, Nova Aguillar, 1995.

ROSA, J. G. Ave, palavra. Rio de Janeiro, Nova Fronteira, 2001.

SZONDI, P. Ensaios sobre o trágico. Trad. Pedro Süssekind. Rio de Janeiro,

Zahar Editores, 2004. 